\title{
Extraconal cystic schwannoma mimicking an orbital dermoid cyst
}

\author{
Schwannoma cístico extraconal simulando um cisto dermóide orbitário
}

Eduardo Damous Feijón ${ }^{1}$, Ana Carla de Souza Nery ${ }^{1}$, Fábio Ramos Caiado ${ }^{2}$, Aline Maria Prehis ${ }^{2}$, Roberto Murillo Limongi $^{3}$

\begin{abstract}
To our knowledge, we report the first case of an extraconal orbital cystic schwannoma in Brazilian literature. The tumor grew slowly and progressively and was associated with minimal eccentric proptosis and diplopia. The radiologic study (orbital computed tomography) revealed a rounded, encapsulated, and extraconal cystic mass in the superior medial region of the right orbit in the supraorbital and supratrochlear nerve topography. An anterior orbitotomy with full excision of the tumor was performed, and the histopathology examination revealed that the tumor was a schwannoma. After the surgery, the patient experienced total remission of his symptoms.
\end{abstract}

Keywords: Neurilemmoma diagnosis; Neurilemmoma surgery; Orbital neoplasms; Exophthalmos; X-ray computed tomography

\section{RESUMO}

Os autores relatam o primeiro caso de schwannoma orbitário extraconal cístico relatado na literatura brasileira. O tumor apresentou aparecimento lento e progressivo, associado a proptose excêntrica e diplopia leves. O exame de imagem (tomografia computadorizada de órbita) revelou uma lesão nodular, arredondada, capsulada, extracônica, cística, na região súpero-medial de órbita direita, na topografia do nervo supraorbitário e supra-troclear. O pacientefoi submetido à orbitotomia porvia anterior, comexérese integral da tumoração. O exame histopatológico revelou o diagnóstico de schwannoma. Após a cirurgia, o paciente teve regressão total dos sintomas.

Descritores: Neurilemoma diagnóstico; Neurilemoma cirurgia; Neoplasias orbitárias: Exoftalmia; Tomografia computadorizada por raios $x$

\section{INTRODUCTION}

Schwannomas, also called neurilemmomas, represent approximately $1 \%$ of orbital tumors and are found in $1.5 \%$ of patients with neurofibromatosis type $1^{(1,2)}$. Cystic lesions, such as dermoid cysts or mucoceles of the orbit, are often encountered, but cystic schwannomas are extremely rare ${ }^{(3)}$. Schwannomas are slow-growing tumors usually found in middle-aged patients and can occur in isolation or in patients with neurofibromatosis. Schwann cells proliferate in schwannomas, forming tumors that originate focally in the nerve with a nodular or fusiform shape. Schwannomas are encapsulated tumors covered with stretched perineural cells and may sometimes cause bone indentation. These tumors usually originate from a sensory nerve and can occur in any part of the orbit, most commonly in the sensory branches of the ophthalmic division of the trigeminal nerve, but they may also arise from the third, fourth, and sixth cranial nerves $s^{(1,2,4)}$. Radiologically, they appear as isolated lesions, either intraor extraconal, with smooth edges and a rounded or fusiform (most common) shape following the anteroposterior axis of the orbit. They are silent lesions that do not usually affect visual acuity and can cause a slow and progressive proptosis as they increase in size ${ }^{(5)}$.

Here, we present the case of a middle-aged man with an extraconal orbital cystic schwannoma in the supraorbital and supratrochlear nerve region, causing painless eccentric proptosis and diplopia. To the best of our knowledge, this is the first case of an orbital cystic schwannoma in Brazil.

\section{CASE REPORT}

A 47-year-old man with a history of right-sided proptosis and occasional diplopia presented a tumor in the upper medial region of the right orbit (Figure $1 \mathrm{~A}$ ). The patient reported that the tumor developed over a period of approximately two or three years, with a slow, progressive, and painless growth.

External examination revealed a visible tumor in the upper medial region of the right orbit and minimal eccentric proptosis and exotropia. The tumor had a fibroelastic consistency, was not adhered to the deep planes, and was mobile on palpation. Visual acuity was 20/20 in both eyes, and there was a mild limitation of the supra adduction of the right eye. Exophthalmometry was $22 \mathrm{~mm}$ in the right eye and $21 \mathrm{~mm}$ in the left eye as measured with a Hertel exophthalmometer. Slit-lamp examination revealed a minimal temporal episcleritis in the right eye. Further, tonometry and the fundus were normal.

Orbital computed tomography (CT) showed an extraconal nodule with the following characteristics: encapsulated, rounded, with well-defined limits, cystic, located on the medial and upper region of the right orbit, and measuring approximately $2.5 \mathrm{~cm}$ in its longest axis (Figure $1 \mathrm{~B}$ ).

The patient underwent surgery to remove the tumor under local anesthesia with sedation. He was subjected to an orbitotomy with an anterior approach. A retroseptal cystic mass was found medially and above the levator aponeurosis that was not attached to the periorbital membrane of the orbital wall. The nodular mass was completely
Funding: No specific financial support was available for this study.

Disclosure of potential conflicts of interest: None of the authors have any potential conflict of interest to disclose.

Corresponding author: Eduardo D. Feijó. Av. Faiad Hanna, 235 - Anápolis, GO - 75080-410 - Brazil E-mail: eduardodff@yahoo.com.br 
excised (Figure 2 A). Histopathological examination revealed a benign tumor of nerve sheath cells, showing Antoni A and B cells with cystic degeneration, which confirms the diagnosis of orbital cystic schwannoma (Figure 2 B).

After the surgery, the patient reported improvement of the diplopia and proptosis. One year postoperatively, the patient has no detectable signs of recurrence as confirm ed by orbital CT.

\section{DISCUSSION}

Schwann cells are neuroglia cells of the peripheral nervous system that form myelin sheaths around the peripheral axons. Schwannomas are benign nerve sheath tumors that occur in isolation in the orbit in 1\% of cases and are sometimes associated with neurofibromatosis ${ }^{(1-11)}$. Although orbital cystic lesions are often encountered,
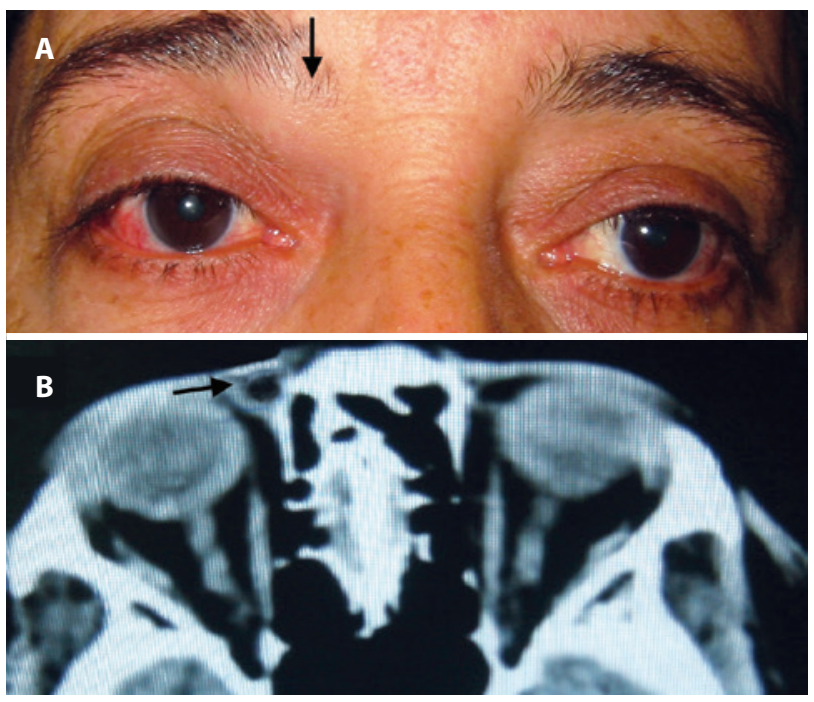

Figure 1. A) The tumor in the supraorbital/supratrochlear nerve topography (arrow). B) Computerized tomography showing a nodular, encapsulated, cystic tumor in the upper medial region of the orbit (arrow).
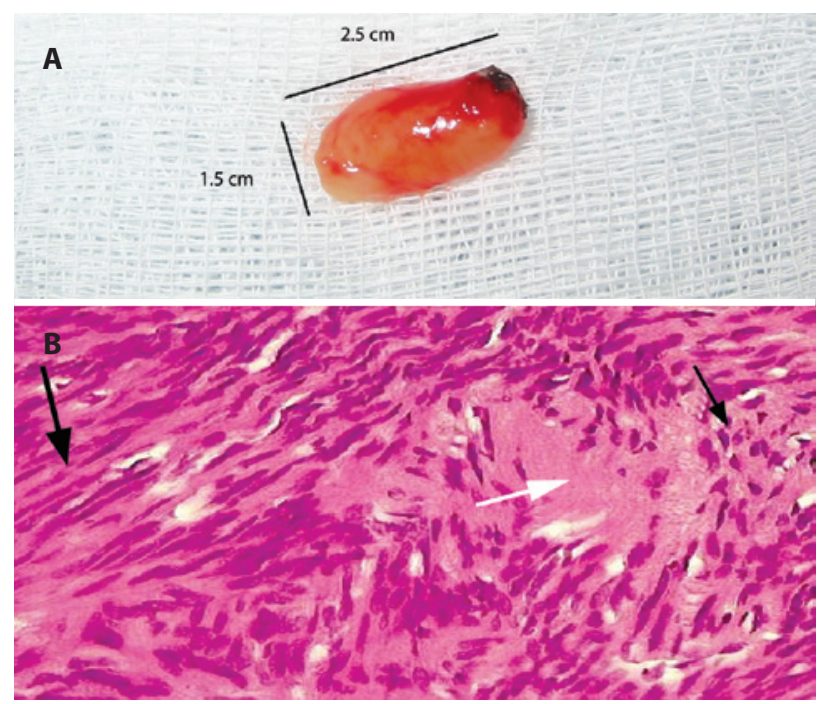

Figure 2. A) The macroscopic appearance of the tumor, measuring $1.5 \times 2.5 \mathrm{~cm}$. B) Black arrows-major: Antoni A cells; minor: Antoni B cells; white arrow: Verocay bodies and cystic areas. they are mostly dermoid cysts and mucoceles, and orbital cystic schwannomas are extremely rare ${ }^{(2)}$.

This case report presents findings that first led to the diagnosis of a dermoid cyst. The nodular encapsulated cystic lesion found on the orbital CT and the localization near frontonasal bone suture led us to suspect choristoma. However, most of the choristomas are congenital tumors, which differ from the tumor found in this report. Another potential diagnosis is an long-lasting old tumor that had not been noticed previously ${ }^{(5)}$.

Diplopia and eccentric proptosis are more common in intraconal tumors. Extraconal tumors, as reported in the present case, have an insidious onset and slow growth and usually cause minimal changes in the orbital structures. Orbital schwannomas usually originate from the ophthalmic division of the trigeminal nerve and most commonly form in the supraorbital nerve and supratrochlear nerve path. Thus, they can cause lateral lower eccentric mild proptosis, as shown in the present case $\mathrm{e}^{(1-4)}$. Diplopia can transpire due to the restriction of eye movement caused by the mechanical effect of the tumor, which was observed in the present study ${ }^{(1-4)}$.

Treatment of orbital schwannomas consists of surgical removal of the tumor, which should be fully removed with its capsule intact. In some cases, depending on the degree of adherence to the tissues, partial resection can happen, which may increase the risk of tumor recurrence. The surgical approach depends on the location of the tumor. In this case, we used anterior orbitotomy restricted to the medial portion of the upper eyelid crease, with full access to the lesion and complete resection ${ }^{(8-11)}$.

There are no clinical or radiological pathognomonic signs for this type of tumor, and multiple presentations have been found ${ }^{(1-6)}$. However, the histopathology of this type of tumor is very characteristic. In our report, the tumor had cellular areas consistent with an Antoni A pattern and hypocellular areas consistent with an Antoni B pattern. Further, there were cystic areas within the tumor, and these findings are consistent with a diagnosis of cystic orbital schwannoma ${ }^{(1,2,4,7-11)}$. In Antoni A pattern, tissue cells are spindle shaped and compactly arranged; conversely, in Antoni B pattern, the cells are loosely arranged, the extensions are not oriented, and the nuclei are round, rather than elongated $(1,3,5,7)$

Some solid benign orbital schwannomas have been previously reported in the Brazilian literature (Table 1). In 1986, Imamura et al.(6) reported the first case of orbital schwannoma in Brazil, describing an intraconal, solid, and benign tumor in a 29-year-old man. Additionally, Maciel et al. ${ }^{(10)}$ reported an extraconal solid lesion in the supraorbital nerve topography in a 14-year-old male. In all of these cases, the tumor was completely excised, and no recurrences were found.

A very small percentage of schwannomas are malignant, which are known as neurofibrosarcomas. Histopathological findings include classic Antoni A and B cells associated with atypical mitotic figures ${ }^{(1-11)}$. Malignant transformation of solid orbital schwannomas has been previously reported ${ }^{(7-9)}$.

Isolated cases of orbital cystic schwannomas have been reported worldwide (Table 2).

All cystic orbital schwannomas reported in the international literature have been benign tumors. These can show cystic degeneration and may present a mixed radiological pattern, with solid and cystic areas inside, which was confirmed in our report. The exact mechanism of the cystic degeneration of this type of tumor remains unknown. Speculative mechanisms include an insufficient vascular supply resulting in necrosis and cystic changes, hemorrhage into the tumor with blood absorption, and hyaline degeneration leading to cyst formation (2).

Lam et al. ${ }^{(2)}$ reported a large paramedian cystic mass displacing the right globe downward and laterally; a presumptive diagnosis of frontal mucocele was made, although the postsurgical histological exam revealed schwannoma. This finding is consistent with the results from our report that the radiologic image could be consistent with a dermoid cyst. Hayashi et al. ${ }^{(1)}$ reported an extraconal cystic schwannoma above the levator palpebrae muscle that was removed 
Table 1. Schwannomas reported in the Brazilian literature

\begin{tabular}{|c|c|c|c|c|}
\hline Author & Patient & Localization & CT findings & Pathologic findings \\
\hline Imamura et al. 1986(6) & Male, $29 y$ & Intraconal & Solid lesion, intraconal space & Antoni A and B cells, benign tumor \\
\hline Monteiro et al. 1994(7) & Female, 68 y & Intraconal & Solid lesion, intraconal space & Antoni A and B cells, anaplasic cell figures, malignant tumor \\
\hline Bison et al. 1996 $6^{(8)}$ & Male, 39 y & Intraconal & Solid lesion, intraconal space & Antoni A and B cells, atypical mitotic figures, malignant tumor \\
\hline Távora et al. 1999(9) & Male, 42 y & Extraconal, medially & Solid lesion, extraconal space & Antoni A and B cells, atypical mitotic figures, malignant tumor \\
\hline Maciel et al. $2001^{(10)}$ & Male, 14 y & $\begin{array}{l}\text { Supraorbital nerve } \\
\text { topography }\end{array}$ & $\begin{array}{c}\text { Solid lesion, supraorbital } \\
\text { topography }\end{array}$ & Antoni $A$ and $B$ cells, benign tumor \\
\hline Coutinho et al. 2014 ${ }^{(11)}$ & Female, 10 y & Upper eyelid & Solid lesion, upper eyelid & Antoni A predominant, benign tumor \\
\hline
\end{tabular}

$\mathrm{y}=$ years; $\mathrm{CT}=$ computed tomography

Table 2. Cystic orbital schwannomas reported worldwide

\begin{tabular}{|c|c|c|c|c|}
\hline Author & Patient & Localization & CT findings & Pathologic findings \\
\hline Lam et al. $1997^{(2)}$ & Male, 52 y & Extraconal, paramedian & $\begin{array}{l}\text { Large paramedian cystic lesion, } \\
\text { extraconal }\end{array}$ & Antoni $\mathrm{A}$ and $\mathrm{B}$ cells, benign tumor \\
\hline Tsuzuki et al. $2000^{(3)}$ & Female, 62 y & Intraconal & Cystic lesion & Antoni A predominant, benign tumor \\
\hline Subramanian et al. $2005^{(5)}$ & Female, 63 y & Intraconal & Intraconal mass with cystic spaces & Antoni $A$ and $B$ cells, benign tumor \\
\hline Gündüz et al. 2011(4) & Male, 40 y & $\begin{array}{l}\text { Extraconal, orbit } \\
\text { medial wall }\end{array}$ & Extraconal mass, bilobed, cystic & Antoni A predominant and Antoni B cells, benign tumor \\
\hline Hayashi et al. 2012(1) & Female, 65 y & $\begin{array}{l}\text { Frontal nerve } \\
\text { topography }\end{array}$ & $\begin{array}{c}\text { Cystic lesion, extraconal, above } \\
\text { levator muscle }\end{array}$ & Antoni $\mathrm{A}$ and $\mathrm{B}$ cells, benign tumor \\
\hline
\end{tabular}

$\mathrm{y}=$ years; $\mathrm{CT}=$ computed tomography.

via a frontal craniotomy with orbital unroofing; a diagnosis of frontal nerve cystic schwannoma was made. Tsuzuki et al.(3) and Subramanian et al. ${ }^{(5)}$ reported intraconal cystic schwannomas; both cases had symptoms of visual loss, diplopia, and proptosis.

Although it has been reported that schwannomas occur in about $1 \%$ of orbital tumors, surgeons need to be aware that the absence of pathognomonic signs and orbital anatomy complexity can lead to misdiagnoses ${ }^{(3)}$.

Schwannomas should be included in the differential diagnosis of any orbital cystic lesion. Correct exams and appropriate surgical management are essential for early diagnosis, good surgical outcome, and decreased rates of recurrence ${ }^{(1-10)}$.

\section{REFERENCES}

1. Hayashi Y, Watanabe T, Kita D, Hayashi Y, Takahira M, Hamada J. Orbital cystics chwannoma originating from the frontal nerve. Case Rep Ophthalmol Med. 2012;2012:604574. doi: $10.1155 / 2012 / 604574$
2. Lam DS, NG JS, To KF, Abdulah V, Liew CT, Tso MO. Cystic schwannoma of the orbit. Eye (Lond). 1997;11(Pt 6):798-800

3. Tsuzuki N, Katoh H, Ohnuki A, Ishihara S, Miyazawa T, Nawashiro H, Shima K. Cystic schwannoma of the orbit: case report. Surg Neurol. 2000;54(5):385-7.

4. Gündüz K, Kurt RA, Erden E. Orbital schwannoma with fluid-fluid levels on MRI Ophthal Plast Reconstr Surg. 2011;27(3):e51-4

5. Subramanian N, Rambhatia S, Mahesh L, Menon SV et al. Cystic schwannoma of the orbit. Orbit. 2005 Jun:24(2):125-9.

6. Imamura PM, Settanni FA, Stavale, JN. Neurilemoma oftálmico. Arq Bras Oftalmol. 1986;49(3):89-94.

7. Monteiro ML, Marantes CR, Cunha SL. Schwannoma malígno da órbita associado a proptose e ectasia posterior do globo ocular. Arq Bras Oftalmol. 1994;57(6):400-2.

8. Bison SH, Vital Filho J, Cursino JW, Lancellotti CL. Schwannoma maligno de órbita. Arq Bras Oftalmol. 1996;59(6):608-10.

9. Távora DB, Monte FQ, Guedes Júnior EO. Evolução singular de um schwannoma maligno da órbita. Rev Bras Oftalmol. 1999:58(11):831-5.

10. Maciel VS, Marback EF, Sé DC, Marback RL. Neurilemoma benigno do nervo supraorbitário. Rev Bras Oftalmol. 2001;60(1):66-9.

11. Coutinho MS, Meyer I, Jungmann P, Souza Filho JP. Schwannoma em pálpebra superior esquerda em criança de 10 anos. Rev Bras Oftalmol. 2014;73(2):117-9. 